\section{Vagt om røykeavvenning}

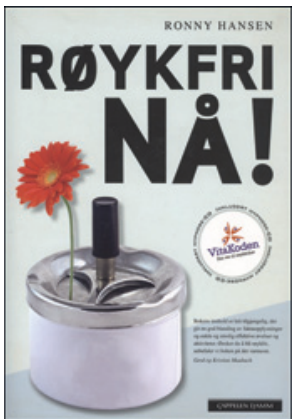

Ronny Hansen

Røykfri nå!

159 s, ill, CD. Oslo: Cappelen Damm, 2012.

Pris NOK 349

ISBN 978-82-02-37250-7

Hensikten er åpenbar, nemlig å få personer som leser boken til å bli røykfrie. Som i flere andre røykeavvenningsbøker henviser forfatteren også til en spesiell metode, her kalt Vita-koden, som bl.a. baserer seg på elementer av hypnose som fører til at man klarer «å forbigå den kritiske sansen». I Vita-koden inngår også «Emotional Freedom Technique» (EFT) som skal påvirke «energiflyten i kroppen». Denne teknikken innbefatter en tappeteknikk på 15 forskjellige punkter på kroppen samtidig som man sier bestemte setninger/affirmasjoner. Ambivalens, det å ønske å slutte, men likevel fortsette, forklares som en ubalanse mellom det bevisste og ubevisste sinn. Det forklares slik at røykeuvanen styres av det ubevisste sinn (følelsene), mens viljestyrken sitter i det bevisste sinn (fornuften). Boken inneholder mange vanlige råd ved røykeavvenning uten noen klar avgrensning til hva som er spesifikt for Vita-koden.

Det er tre hoveddeler: del 1, Forberedelsesfasen, med 12 kapitler, del 2, Programmet starter - 1 uke igjen, med tre kapitler og del 3, Du er røykfri, med tre kapitler.

I del 1 inngår bl.a. nokså vanlige elementer i røykeavvenning, nemlig avkledning og avsløring av røykevanen, det å utfordre illusjonen om at røyken gjør deg rolig, unnskyldninger for å fortsette, nikotinavhengighet, motivasjon og viljestyrkens betydning og modningsprosessen mot røykfrihet. Når det nærmer seg røykfrihet i del 2 understreker forfatteren hvor viktig nulltoleransen er mot å ta seg en røyk igjen etter røykestopp og gevinster ved røykfrihet. I del 3 beskriver han diverse teknikker for å bekjempe tilløpet til røykesug og selvsabotering. Det er også flere hjemmelekser, f.eks. skal man over 100 ganger per dag si: «Jeg elsker å være sunn, frisk og røykfri.»

Det legges opp til en stadig registrering av motivasjon for å bli røykfri og signering av avtale når motivasjonen er sterk nok. For øvrig kan man velge mellom to forskjellige tilnærminger, enten tre timers hypnose/hypnoterapi eller (aktuelle) bok med CD, som inneholder opplest motivasjons- og hypnosetekst sammen med rolig musikk.

Boken inneholder vekselvis en historie om en familiefar som blir røykfri. Han har prøvd å bli røykfri mange ganger tidligere, men får nå nyss om en ny metode som er svært effektiv. Det er selvsagt Vita-koden vi snakker om, og i fortellingen synes metoden å begynne å virke nærmest lenge før han kommer til behandling: «Jeg ble nesten røykfri bare ved å snakke med henne.»

Forfatteren synes særlig å angripe viljestyrkemetoden som omtales, som feil metode. Her hevder forfatteren sågar at man ikke trenger viljestyrke for å bli røykfri, men han understreker samtidig at man må ha et sterkt ønske om å bli det. I selvforherligelsen omtales Vita-koden med: «Så enkelt, så naturlig, så opplagt, så selvfølgelig, så vidunderlig» og «Jeg bruker nå den beste metoden som finnes og som har en eventyrlig suksessrate.» Videre står det: «Alt er skrevet på en måte som gjør at du blir optimalt påvirket i riktig retning. Alt i denne boken er skrevet for å påvirke ditt ubevisste sinn.»

Nikotinavhengighet forklares på en nokså løs og fri måte uten fysiologisk eller farmakologisk tilknytning. Her avkrefter forfatteren at nikotin fører til fysisk avhengighet, samtidig som det kan oppstå abstinenser. Så hevder han også at de som blir røykfrie med Vita-koden, sjelden opplever abstinenser, irritasjon/sinne og vektøkning, uten at han forsøker å forklare hvorfor. Når man våkner den dagen man skal bli røykfri, hevder han at «røyken ikke har noen betydning lenger».
Boken er uten referanser, men med hensyn til Vita-koden henvises det til «årelang klinisk erfaring med behandling av røykere». Det kan være flere grunner til det, men hvis man leser Cochraneoversikter, er ikke hypnoterapi effektivt etter vurderingen av 11 randomiserte studier (1).

Det er flere gode uttalelser som kan brukes i røykeavvenning, men de som jeg personlig blir hengende mest ved er disse: «Den neste røyken skader deg mer enn den forrige» og Henry Fords kjente uttalelse: «Whether you think you can, or you think you can't, you're right.»

Men virker dette? De siste ti årene har jeg fått mange tilbakemeldinger fra pasienter som har hatt nytte av å lese røykeavvenningsbøker, kanskje særlig Allen Carrs kjente bok Endelig ikke-røyker! Uansett blir det for meg likevel for suggestivt og vagt, med til dels sprikende forklaringsmodeller og med et innstendig krav om at leseren må se på Vita-koden som den eneste sannhet. For røykere som godtar disse forutsetningene, kan nok boken ha sin misjon, men jeg vil tro de fleste faller av på hjemmeleksene og de mange instruksjonene og affirmasjonene som skal utføres.

\section{Frode Gallefoss}

Seksjon for lungesykdommer

Sørlandet sykehus

Kristiansand

\section{Litteratur \\ 1. Does hypnotherapy help people who are trying to stop smoking. Cochrane summaries 6.10.2010. http://summaries.cochrane.org/CD001008/does- hypnotherapy-help-people-who-are-trying-to-stop-smoking (16.5.2012).}

\section{Jordnær og humoristisk samlivsbok}

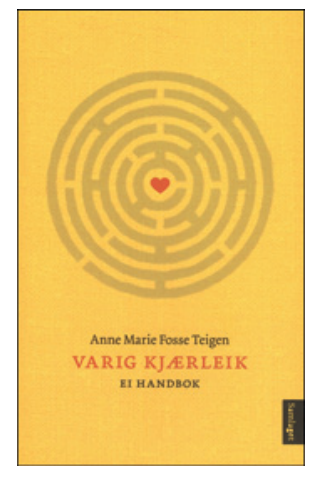

\section{Anne Marie Fosse Teigen Varig kjærleik}

Ei handbok. 180 s. Oslo: Samlaget, 2012. Pris NOK 329

ISBN 978-82-521-8074-9

En jordnær, praktisk og lettfattelig samlivsbok står det på baksiden av boken, og hvert ord er sant. Forfatteren er familieterapeut og innleder med at tanken bak er å presentere kunnskap og verktøy som kan brukes til å styrke den «varige kjærleiken». Hun slår an tonen med diktet til Halldis Moren Vesaas, Kjorleik gjer klok.

Det er ti kapitler: Jakta på det gode parforholdet, Hjernen er ikkje aleine..., Kjenslefilosofar, Mang slags kjarleik, Kjenslerei innføring, Handtering av sterke kjensler, Om att og om att-irritasjonane, Svik, krenking, hemn og reparasjon, Du og eg, Emil... og La lykka gro!

Boken avrundes med tre jukselapper for kjærester og en oppskrift på tufte-samtaler: tid, utforsking, forståelse, tålmodighet, empati.

Den har mange gode, praktiske råd både til oss som terapeuter, og oss som lever i parforhold. Teksten er morsom og tilsynelatende lettlest, men gir mye å tenke på, så den tar sin tid likevel. Forfatteren skriver friskt og freidig på et smidig og vakkert nynorsk i Are Kalvø-stil, og Kalvø blir da også takket i etterordet. Har man lyst til å lese mer, finnes det henvisninger til det.

\section{Astrid Nøklebye Heiberg}

Oslo 